iD https:/ orcid.org/0000-0003-3993-2182

\title{
Nadużycie prawa w procesie karnym
}

\begin{abstract}
This paper analyses the issue of abuse of rights in criminal proceedings. Based on jurisprudence and doctrinal writings about the criminal proceedings, an attempt was made to provide a separate definition of this concept. Then the focus was shifted to seeking a legal basis for sanctioning manifestations of abuse of procedural right, referring to the current legal status, as well as formulating de lege ferenda postulates in this respect.
\end{abstract}

Keywords: abuse of right in criminal proceedings, abuse of procedural right, abuse of right, objectives of criminal procedure, criminal procedure

\section{Wprowadzenie}

Zagadnienie nadużycia prawa procesowego, choć zakorzenione w postępowaniu cywilnym, od blisko dwóch dekad stanowi również przedmiot dociekań nauki prawa karnego procesowego. Pomimo systematycznie podejmowanych prób przedstawicielom doktryny procesu karnego jak dotąd nie udało się wypracować wspólnych wniosków tak co do treściowej zawartości tego pojęcia, jak i możliwych metod przeciwdziałania temu zjawisku. Różne są zresztą nawet perspektywy badawcze. W większości prac dominuje spojrzenie na omawiane zagadnienie z punktu widzenia biernej strony procesu ${ }^{1}$, zaś do nielicznych należą pozycje, w których równie dużo miejsca poświęcono nadużyciom ze strony instytucjonalnych

${ }^{1}$ M. NiemölLer: Nadużycie prawa $w$ procesie karnym. Prok. i Pr. 2002, nr 9, s. 98, przyp. 9; S. Waltoś: O obstrukcji procesowej, czyli kilka uwag o nadużyciu prawa procesowego. W: W kręgu teorii i praktyki prawa karnego. Księga pamiątkowa poświęcona pamięci prof. A. Wąska. Red. L. LeszczyńsKi, E. Skrętowicz, Z. HoŁdA. Lublin 2005, s. 615; M. WARCHOє: Pojęcie „nadużycia prawa” w procesie karnym. Prok. i Pr. 2007, nr 11, s. 54 i cytowana tam literatura obcojęzyczna. 
uczestników procesu². Na skalę rozbieżności wskazuje również to, że zdaniem części autorów ochrona przed instrumentalizacją prawa powinna mieć miejsce w szczególności w stadium postępowania przygotowawczego $^{3}$, gdy tymczasem zdaniem innych do nadużycia prawa dochodzi najczęściej dopiero na etapie postępowania jurysdykcyjnego ${ }^{4}$.

Zagadnienie nadużycia prawa podmiotowego - choć zdecydowanie szerzej w kontekście uprawnień o charakterze prawnomaterialnym - zostało już dogłębnie zbadane na gruncie ogólnej teorii prawa ${ }^{5}$. Podstawą niniejszej pracy jest zestawienie wyników tych badań z dorobkiem o charakterze stricte karnoprocesowym, a jej celem próba skonstruowania definicji badanego pojęcia właśnie na potrzeby tej gałęzi prawa, jak również udzielenie odpowiedzi na pytanie o możliwość odnalezienia regulacji potwierdzających istnienie tej instytucji de lege lata, ewentualnie o celowość jej implementowania na grunt procesu karnego w przyszłości.

\section{Treść pojęcia}

Pomimo zasygnalizowanych wcześniej rozbieżności wśród przedstawicieli nauki prawa karnego procesowego można twierdzić, że dotychczasowe prace $\mathrm{z}$ tego zakresu, oparte w przeważającej mierze na dorobku teoretyków prawa, zaowocowały przyjęciem dość spójnych założeń terminologicznych, stanowiących wszak punkt wyjścia dla bardziej szczegółowych rozważań ${ }^{6}$, a które stały się podstawą do sformułowania poniższej definicji.

$\mathrm{Z}$ nadużyciem prawa procesowego mamy do czynienia wtedy, gdy uczestnik procesu używa, poprzez swoje działanie lub zaniechanie ${ }^{7}$, wynikającego z przepisów prawa procesowego uprawnienia w sposób sprzecz-

2 Ł. CoRA: Gradacja nadużycia prawa $w$ procesie karnym (zarys teoretyczny). SP 2019, nr 1 , s. 113 i nast.

3 Ibidem, s. 133.

${ }^{4}$ J. Kosonoga: Oddalenie obstrukcyjnego wniosku dowodowego. IN 2019, nr 1, s. 22.

${ }_{5}$ Zob. Nadużycie prawa. Red. H. IzDEBSKI, A. STĘPKOwSKI. Warszawa 2003, passim.

6 Trafnie zwraca na to uwagę Ł. Cora: Gradacja nadużycia prawa..., s. 116-117.

7 Co prawda de lege lata niełatwo znaleźć przykład sytuacji, w której prawodawca uznaje, że strona nie ma obowiązku dokonywania danej czynności, a mimo to nieskorzystanie przez nią z tego uprawnienia jest w konkretnym układzie procesowym sprzeczne z celem normy, tym niemniej nadużycie prawa polegające na zaniechaniu - przynajmniej teoretycznie - jest możliwe do wyobrażenia. Częściej jednak szereg zaniechań przybiera ostatecznie formę nadużycia dopiero za sprawą działania; zob. post. SA w Krakowie z dnia 14 października 1992 r., II AKz 218/92. LEX nr 27794, gdzie podejrzany najpierw odmawiał dostarczenia określonych dowodów (zaniechanie), a następnie podniósł zarzut przewlekłości postępowania przygotowawczego (działanie); podobnie SA w Krakowie w wyr. z dnia 20 maja 1999 r., II AKa 71/99. LEX nr 38103. 
ny z celem (celami), dla którego zostało ono w tych przepisach przewidziane ${ }^{8}$, a zatem gdy pomimo formalnej zgodności pomiędzy dokonywaną czynnością prawną a treścią normy prawnej, z której uprawnienie do przeprowadzenia tej czynności się wywodzi, jej dokonanie należy w konkretnym przypadku uznać za sprzeczne z ratio legis owej normy ${ }^{9}$.

Niektórzy dodają, że opisane zachowanie powinno również wywoływać negatywne konsekwencje w sferze interesu jednej z konkurujących stron procesowych ${ }^{10}$. Moim zdaniem cechy tej, choć bez wątpienia typowej dla nadużycia prawa, nie można uznawać za element konstytutywny tego pojęcia. Po pierwsze, organ oceniający takie zachowanie może w momencie podejmowania decyzji w przedmiocie uznania go za przejaw nadużycia prawa nie być jeszcze w stanie rozstrzygnąć, czy badana przezeń czynność procesowa rzeczywiście nie wywoła w przyszłości zamierzonego przez stronę skutku, tj. nie spowoduje negatywnych konsekwencji w sferze interesów pozostałych uczestników. Przykładowo zachowanie podjęte przed sądem I instancji może być w założeniu nadużywającego nakierowane na osiagnnięcie określonego celu dopiero w postępowaniu apelacyjnym czy nawet kasacyjnym. Po drugie, sam fakt wykroczenia poza cel normy per se prowadzi zawsze do swoistego pokrzywdzenia porządku prawnego, wymiaru sprawiedliwości oraz poczucia praworządności i sprawiedliwości (male nostro iure uti non debemus). Do pewnego stopnia tożsame względy przemawiają za wyróżnianiem na gruncie prawa karnego materialnego tzw. przestępstw bez ofiar. Tym samym nadużycie prawa procesowego już ze swej istoty, bez względu na okoliczności konkretnego przypadku, wywołuje negatywne konsekwencje w sferze interesu organu procesowego, który obowiązany jest dbać o prawidłowy (a zatem m.in. zgodny z celami procesu) przebieg postępowania, w związku z czym nie powinno się wymagać, aby oceniane przez ten pryzmat zachowanie naruszało również interes konkurującej strony. Nadużycie, z którego dokonujący je odnosi lub zamierza odnieść jakąś korzyść, może być dla interesu jego przeciwnika procesowego - przynajmniej teoretycznie - neutralne, tzn. ani korzystne, ani niekorzystne.

W części krajów, w których przyjęto koncepcję nadużycia prawa procesowego, uwagę zwraca się również na stronę podmiotową tego typu zachowań $^{11}$. Uważam jednak, że i tę cechę nadużycia prawa należy uznać

${ }^{8}$ Por. M. Warcho£: Pojęcie „nadużycia prawa”..., s. 48; Ł. CorA: Gradacja nadużycia prawa..., s. 119-120; wyr. SA w Gdańsku z dnia 15 maja 2014 r., II AKa 101/13. LEX nr 1532571.

9 Ł. CoRA: Gradacja nadużycia prawa..., s. 120.

10 Ibidem.

11 A. Lach: Nadużycie procesu i uprawnień procesowych. W: Problemy prawa i procesu karnego. Księga poświęcona pamięci Profesora Alfreda Kaftala. Red. G. RejMan et al. Warszawa 2008, s. 230. 
za definicyjnie nieistotną. Dla oceny prawidłowości badanej czynności a zatem dla oceny zachowania przy jej przeprowadzaniu standardu sprawiedliwości proceduralnej - nie ma większego znaczenia ewentualna zła wola po stronie nadużywającego, ale jedynie obiektywnie istniejąca niezgodność pomiędzy zachowaniem a celem normy.

Z zaprezentowanej wcześniej definicji wynika, że desygnatami pojęcia „nadużycie prawa procesowego" są zachowania należące do kategorii pośredniej pomiędzy zachowaniami w pełni legalnymi, a zachowaniami jednoznacznie sprzecznymi z określoną normą prawną. Legalne jest w rozważanym kontekście to, co zgodne z treścią i celem normy, zaś nielegalne to, co niezgodne z treścią lub celem normy. Pomimo zastosowania spójnika wyrażającego alternatywę łączną nie sposób wyobrazić sobie zachowanie, które byłoby sprzeczne z treścią normy, a zarazem zgodne z celem jej wprowadzenia. Chodzi tu raczej o zaakcentowanie, że w przypadku ustalenia niezgodności czynności z treścią normy nie ma potrzeby ani sensu badania jej zgodności również z ratio leglis rozpatrywanej regulacji (zob. tabelę nr 1).

Tabela nr 1. Ocena zachowań procesowych przez pryzmat ich zgodności z treścią i celem normy

\begin{tabular}{|c|c|c|}
\cline { 2 - 3 } \multicolumn{1}{c|}{} & Zgodność z treścią normy & Zgodność z celem normy \\
\hline Działanie legalne & TAK & TAK \\
\hline Nadużycie prawa & TAK & NIE \\
\hline Naruszenie prawa & NIE & TAK/NIE \\
\hline
\end{tabular}

Źródło: opracowanie własne.

Jeżeli więc analizowana czynność jest wprawdzie niezgodna z celem wprowadzenia unormowania stanowiącego podstawę do jej dokonania, ale równocześnie narusza - chociażby tylko częściowo - treść normy, to nie jest ona przejawem nadużycia, ale wyłącznie naruszenia prawa ${ }^{12}$. Warto w związku z tym zauważyć, że w wyniku działań ustawodawczych to, co pierwotnie było niezgodne jedynie z niewysłowionym celem danej normy, na skutek zmiany brzmienia konkretnego przepisu może się stać

12 Odmiennie M.G. Plebanek, którego zdaniem przez nadużycie praw procesowych należy rozumieć każdy wypadek takiego skorzystania przez uczestnika z postępowania cywilnego, które służy innym celom niż uzyskanie ochrony praw podmiotowych, tj. m.in. skorzystania w sposób obiektywnie sprzeczny (czy też obiektywnie nieuzasadniony) z treścią przepisów procesowych - zob. M.G. PLEBANEK: Wykonanie nieprawomocnego nakazu zapłaty zaopatrzonego $w$ klauzulę wykonalności a zagadnienia nadużycia prawa procesowego i podmiotowego. Glosa do uchwały Sąu Najwyższego z dnia 7 października 2009 r. (III CZP 68/09). „Polski Proces Cywilny” 2011, nr 1, s. 159; IDEM: Nadużycie praw procesowych w postępowaniu cywilnym. Warszawa 2012, s. 74 i 544. 
sprzeczne z treścią tej samej normy. Przykładem tego typu sytuacji jest chociażby wprowadzenie do porządku prawnego art. 41a Kodeksu postępowania karnego ${ }^{13}$. Składanie wniosków o wyłączenie sędziego opartych na podstawach faktycznych już raz ocenionych jako niewystarczające było do czasu wejścia w życie tego przepisu sprzeczne z celem przepisów dotyczących wyłączenia sędziego, ale już nie z ich treścią ${ }^{14}$. Wprowadzenie do systemu normy o treści „Nie składaj wniosku o wyłączenie sędziego, który byłby oparty na tych samych podstawach faktycznych, co wniosek rozpoznany już wcześniej” oznacza, że opisywane zachowanie należy potraktować jako jednoznacznie sprzeczne z jej dyspozycją, a w konsekwencji za nienadające się do zakwalifikowania jako nadużycie. Tym samym za błędne uznaję egzemplifikowanie przejawów nadużycia prawa procesowego przy użyciu przypadków, w których w rzeczywistości dochodzi do jego naruszenia.

Przykładowo według S. Waltosia przejawem nadużycia prawa procesowego jest wysyłanie do prokuratury zawiadomień o podejrzeniu popełnienia przestępstwa oszustwa, mimo że opisywany przez zawiadamiającego czyn jest jedynie konfliktem cywilnoprawnym, a korzystanie z drogi karnoprocesowej zamiast wniesienia pozwu o zwrot długu podyktowane jest chęcią wymuszenia na dłużniku - mającym stać się wkrótce podejrzanym - określonych ustępstw ${ }^{15}$. Z kolei zdaniem $€$. Cory z nadużyciem prawa procesowego mamy do czynienia w przypadku, w którym oskarżony lub jego obrońca wykonują prawo do obrony przy pomocy nakłaniania świadków do składania fałszywych zeznań albo gdy sąd korzysta z uprawnienia do odroczenia rozprawy i zakreślenia oskarżycielowi publicznemu terminu do przedstawienia dodatkowych dowodów w trybie art. 396a k.p.k., pomimo że samodzielne usunięcie istotnych braków postępowania przygotowawczego przez sąd nie uniemożliwiłoby mu wydania prawidłowego orzeczenia ${ }^{16}$. W rzeczywistości we wszystkich tych przypadkach mamy do czynienia z kategorią naruszenia prawa, nie zaś jego nadużycia.

W pierwszym przykładzie dochodzi do naruszenia wynikającej z art. $304 \$ 1$ zd. 1 k.p.k. normy „Nie zawiadamiaj organów ścigania o czynie, o którym wiesz, że nie jest przestępstwem ściganym z urzędu", na które reakcją powinno być wydanie „zwykłej” decyzji o odmowie wszczęcia postępowania przygotowawczego $\mathrm{z}$ uwagi na brak znamion czynu za-

${ }^{13}$ Ustawa z dnia 6 czerwca 1997 r. - Kodeks postępowania karnego, Dz.U. 2018, poz. 1987 ze zm.

14 Zob. post. SA w Krakowie z dnia 30 listopada 1995 r., II AKo 161/95. LEX nr 28318.

15 S. Waltoś: O obstrukcji procesowej..., s. 620.

${ }^{16}$ Ł. Cora: Gradacja nadużycia prawa..., s. 127 i 131. 
bronionego (art. $17 \S 1$ pkt 2 k.p.k.) ${ }^{17}$. Z kolei zachowanie opisane w drugim z przywołanych przykładów stanowi naruszenie zadekretowanej w art. 6 k.p.k. zasady (wszak również będącej normą) prawa do obrony. Jak trafnie przyjmuje się $\mathrm{w}$ literaturze przedmiotu, zasada ta obowiązuje na gruncie danego systemu prawnego, w związku z czym granice prawa do obrony wyznaczone są (limitowane) przez przepisy prawa ${ }^{18}$. Tym samym wykonywanie go przy użyciu działań wypełniających znamiona przestępstwa podżegania do składania fałszywych zeznań nie jest przejawem nadużycia tego prawa, ale w ogóle nie mieści się w jego granicach i w związku $\mathrm{z}$ tym nie jest korzystaniem $\mathrm{z}$ prawa do obrony $\mathrm{w}$ rozumieniu kodeksowym ${ }^{19}$. Innymi słowy, z wyjątkiem sytuacji wskazanych wprost w ustawie (zob. art. 168a k.p.k.), prawa nie można wykonywać przy pomocy bezprawia. W trzecim przypadku sąd korzysta z określonej instytucji procesowej pomimo niespełnienia się jednej z przesłanek jej zastosowania, tym samym dopuszczając się ewidentnej obrazy art. 396a $\S 1$ k.p.k. Przykładów uznawania za desygnat pojęcia „nadużycie prawa” zachowań w rzeczywistości będących jego naruszeniem jest oczywiście znacznie więcej. Wszystkie one pokazują, że - pomimo przyjęcia prima facie wspólnych podstaw terminologicznych - w literaturze z zakresu prawa karnego procesowego nadal brakuje zgodności co do istoty komentowanego mechanizmu.

Uważam, że proponowana w niniejszej pracy teza o zachodzeniu pomiędzy nadużyciem i naruszeniem prawa stosunku wykluczania się zdecydowanie bardziej odpowiada potrzebom praktyki aniżeli uznawanie, że to samo zachowanie może niekiedy stanowić desygnat obu tych pojęć. Wynika to z samej funkcji konstrukcji nadużycia prawa, której powodem wyodrębnienia była chęć wyposażenia organu procesowego w narzędzie służące do skutecznego przeciwdziałania czynnościom, które choć w oczywisty sposób stanowią nadużycie „hojności” ustawodawcy de facto nie są zakazane i w związku z tym mieszczą się w graniach wy-

17 Rozwiązanie takie przedstawia zresztą również sam autor przykładu - zob. S. WALToś: O obstrukcji procesowej..., s. 620; podobnie A. LACH: Nadużycie procesu i uprawnień..., s. 231 .

18 Tak trafnie J. MajEwski: Granice dozwolonej obrony w procesie karnym a ryzyko popetnienia przestępstwa przez adwokata wykonującego czynności obrończe. W: Adwokatura w systemie organów ochrony prawnej. T. 3. Red. J. GiezeK. Warszawa 2010, s. 56; J. SKonUPKA. W: Kodeks postępowania karnego. Komentarz. Red. IDEm. Wyd. 4. Warszawa 2020, s. 37.

19 Por. uchw. SN z dnia 22 września 1995 r., I KZP 31/95. OSNKW 1995, nr 11-12, poz. 74, w uzasadnieniu której Sąd Najwyższy słusznie uznał, że podejrzany nadużył prawa do obrony m.in. poprzez przepisywanie całych, wyjątkowo obszernych akt sprawy; zob. również wyr. SA w Lublinie z dnia 6 lutego 2002 r., II AKa 222/01. KZS 2003, nr 5, poz. 66; post. SN z dnia 19 października 2006 r., V KK 280/06. LEX nr 198075. 
znaczonych treścią norm prawnych ${ }^{20}$. Wtłaczanie w ramy mechanizmu nadużycia prawa procesowego zachowań, co do których organ ma już przecież odpowiednie narzędzia wynikające wprost z treści przepisu (np. możliwość odmowy wszczęcia postępowania przygotowawczego czy pozostawienia kolejnego wniosku o wyłączenie sędziego bez rozpoznania), zdaje się nie przynosić żadnych wymiernych korzyści, stanowiąc przez to przejaw naruszenia fundamentalnej dla nauki zasady ekonomii, powszechnie rozumianej jako zakaz mnożenia bytów ponad potrzebę. Właściwym przykładem nadużycia jest więc m.in. sytuacja, w której prokurator sprzeciwia się wyłączeniu jawności rozprawy jedynie w celu pognębienia oskarżonego i wywarcia na nim presji psychologicznej ${ }^{21}$. Należy zauważyć, że w stanowiącym podstawę omawianego sprzeciwu art. 360 § 2 k.p.k. nie wskazano, czym prokurator powinien się kierować przy podejmowaniu takiej decyzji, a zatem nie sposób mówić, że doszło do naruszenia zakodowanej w komentowanym przepisie normy. Równocześnie jednak nie powinno budzić wątpliwości, że celem wprowadzenia tej regulacji - abstrahując od kwestii zasadności istnienia wskazanego mechanizmu - było wzmocnienie roli prokuratora jako reprezentanta interesu społecznego czy też strażnika praworządności, a nie umożliwienie mu dyskrecjonalnego decydowania o jawności postępowania. Opisywane zachowanie nie jest więc ani w pełni prawidłowym wykonywaniem prawa (sprzeczność z celem), ani też przejawem jego naruszenia (zgodność z treścią), w związku z czym można je uznać właśnie za nadużycie prawa.

Jedynie na marginesie warto wyrazić nadzieję, że koncepcja ta nie będzie wykorzystywana do zawoalowanego podważania zasadności wprowadzenia $\mathrm{w}$ życie regulacji prawnych, co do których podmiot oceniający jest negatywnie nastawiony np. z uwagi na ich - rzekomą lub nawet rzeczywistą - aksjologiczną bezzasadność. Chodzić tu może zwłaszcza o tak kontrowersyjne rozwiązania jak m.in. możliwość wykorzystania w procesie tzw. dowodów nielegalnych czy instytucję przekazania sprawy prokuratorowi w celu uzupełnienia śledztwa. Jak już wielokrotnie wskazywano, opisywana konstrukcja opiera się na niezgodności zachowania z celem normy stanowiącej jego podstawę. Należy jednak pamiętać, że chodzi tu wyłącznie o cel normatywny, tj. ustalony przez samego ustawodawcę (ewentualnie ustrojodawcę), nie zaś o cel, jakiemu - zdaniem podmiotu oceniającego - powinien służyć proces karny czy konkretna instytucja prawna. Tym samym sankcjonowanie zachowań wprawdzie zgodnych z obiektywnie istniejącym celem wprowadzenia danego unormowania (wynikającym z kontekstu normatywnego, w jakim ono funk-

20 C. Contr: L'imputato nel procedimento connesso. Diritto al silenzio e obbligo di verità. Cedam 2003, s. 150. Cyt. za: M. WarchoŁ: Pojęcie „nadużycia prawa”..., s. 24.

21 Tak też Ł. Cora: Gradacja nadużycia prawa..., s. 126. 
cjonuje), ale niezgodnych z systemem wartości oceniającego to zachowanie jest niczym innym jak nadużyciem przez organ procesowy konstrukcji nadużycia prawa (swoistym nadużyciem II stopnia), które nie powinno znajdować oparcia w przepisach prawnych. Omawiany mechanizm ma bowiem służyć kwestionowaniu pojedynczych czynności, nie zaś norm stanowiących ich podstawę. Temu ostatniemu celowi służą odrębne rozwiązania, na czele z kontrolą konstytucyjności.

\section{Podstawa prawna}

W piśmiennictwie karnoprocesowym równie wiele wątpliwości, co sama definicja omawianego pojęcia, wywołała kwestia metod przeciwdziałania przejawom nadużycia prawa przez uczestników procesu karnego. Spór zogniskował się wokół pytania o to, czy obowiązujące ustawodawstwo przewiduje jakąkolwiek podstawę normatywną dla sankcjonowania tego typu zachowań. Jeśli tak, to jaką? Jeśli nie, to czy jednak powinien? Jeśli powinien, to jaki ta podstawa powinna przybrać kształt? Dotychczas w doktrynie prawa karnego procesowego wypracowano dwie przeciwstawne koncepcje, których zasadniczym kryterium rozróżnienia jest stosunek do zasadności wprowadzenia do ustawy procesowej klauzuli wyraźnie zakazującej nadużywania prawa, ewentualnie - patrząc na to samo zjawisko od strony pozytywnej - nakazującej uczestnikom procesu działanie w zgodzie z celami norm stanowiących podstawę ich działań.

Jak pisał M. Niemöller, wprowadzenie ustawowej klauzuli nadużycia prawa procesowego nie prowadziłoby do rozwiązania omawianego problemu, a jedynie do jego przesunięcia w inny obszar ${ }^{22}$. Przeciwko temu sposobowi walczenia z przejawami nieuczciwości procesowej opowiedział się również S. Waltoś, którego zdaniem „Pojawienie się takiego przepisu stworzyłoby okazję do przeróżnych sporów, a jego brzmienia nigdy nie udałoby się doprowadzić do stanu takiej precyzji, który by unicestwiał w zarodku dyskusje interpretacyjne"23. Wydaje się, że obu przywołanym autorom w gruncie rzeczy chodzi dokładnie o to samo, tj. o bezcelowość przenoszenia sporu z pytania o to, które z zachowań stanowią przejaw nadużycia prawa, na pytanie o to, czym właściwie jest owo nadużycie, ponieważ w obu przypadkach organ procesowy nie uzyska jasnej odpowiedzi na pytanie o zbiór zachowań sprzecznych z celem procesu karnego. Zdaniem S. Waltosia skutecznie zwalczać nadużycia prawa procesowego można wyłącznie przy pomocy szczegółowych rozwiązań, wprost odno-

${ }^{22}$ M. Niemöller: Nadużycie prawa $w$ procesie..., s. 99, przyp. 11.

${ }^{23}$ S. Waltoś: O obstrukcji procesowej..., s. 619; tak również A. LaCH: Nadużycie procesu i uprawnień..., s. 235. 
szących się do sytuacji, w jakich nadużycie mogłoby się pojawić ${ }^{24}$. Pogląd ten, $\mathrm{w}$ istocie stanowiący postulat zachowania w tym zakresie status quo, uważam za nietrafny. Jeżeli bowiem z treści danego przepisu wprost - lub po zastosowaniu określonych dyrektyw wykładni - wynika, że nadaje się on (samodzielnie) do przeciwdziałania określonym praktykom uczestników procesowych, to praktyki te - jak już była o tym mowa wcześniej należy uznać za przejawy naruszenia, a nie jedynie nadużycia wysłowionej w nim normy. Przedstawiony wyżej sposób rozumowania zdaje się nie dostrzegać samej istoty tytułowego zagadnienia, które dlatego stanowi wyzwanie dla współczesnego wymiaru sprawiedliwości, że właśnie „wymyka się" treści poszczególnych norm.

Druga grupa autorów opowiada się za koniecznością zaradzenia komentowanemu problemowi na drodze legislacyjnej ${ }^{25}$. Rozwiązanie to znajduje systemowe oparcie $\mathrm{w}$ rozwiązaniach z zakresu postępowania cywilnego, gdzie w ostatnim czasie również zadekretowano - wywodzony już zresztą wcześniej z szeregu innych przepisów - ogólny zakaz wykorzystywania uprawnień procesowych niezgodnie z celem, dla którego je ustanowiono ${ }^{26}$. Wydaje się, że argumentem przemawiającym przeciwko wprowadzeniu zakazu nadużycia prawa procesowego jako odrębnego przepisu nie powinna być jego ewentualna struktura, tj. konieczność skonstruowania go przy użyciu klauzuli generalnej, co samo w sobie wiązać się będzie z powstaniem szeregu wątpliwości interpretacyjnych. Należy bowiem pamiętać, że budowanie przepisów prawnych przy ich użyciu ma przecież także niewątpliwe zalety, w tym zwłaszcza umożliwia dostosowanie ich treści do zmieniających się warunków społecznych (nie wspominając już o tym, że powodem rozbieżności w działalności sądów są równie często wyrażenia o prima facie jednoznacznej zawartości treściowej). W doktrynie postępowania cywilnego wskazywano także, że wyraźne wysłowienie

${ }^{24}$ S. Waltoś: O obstrukcji procesowej..., s. 619.

25 J. Kosonoga: Oddalenie obstrukcyjnego wniosku..., s. 22; por. nieco ostrożniejsze stanowisko Ł. Cory, którego zdaniem istnieje konieczność samego rozważenia wprowadzenia ogólnej klauzuli zakazu nadużywania prawa - zob. Ł. CoRA: Gradacja nadużycia prawa..., s. 133.

${ }^{26}$ Zob. art. $4^{1}$ Ustawy z dnia 17 listopada 1964 r. - Kodeks postępowania cywilnego, Dz.U. 2019, poz. 1460 ze zm.; por. art. 119a i nast. Ustawy z dnia 29 sierpnia 1997 r. Ordynacja podatkowa, Dz.U. 2019, poz. 900 ze zm., gdzie jednym z kryteriów uznania danego zachowania za przejaw unikania opodatkowania jest zestawienie go z „celem ustawy podatkowej lub jej przepisu"; szerzej na temat klauzuli przeciwko unikaniu opodatkowania P. Borszowski: Klauzula przeciwko unikaniu opodatkowania. Wrocław 2017, passim; w kontekście prawa podatkowego zob. również wyr. WSA we Wrocławiu z dnia 21 marca 2019 r., I SA/Wr 1220/18. LEX nr 2656515, w którym istnienie po stronie sądu obowiązku rzeczywistego przeciwdziałania nadużycia prawa, zwłaszcza ze strony organu władzy, uzasadniano m.in. poprzez odwołanie się do arystotelesowskiej Etyki nikomachejskiej. 
w ustawie procesowej normy zabraniającej niewłaściwego postępowania, w tym niewłaściwego i nieuzasadnionego korzystania z instytucji procesowych, przyczyni się również do podniesienia „kultury i świadomości prawnej społeczeństwa”, a także dostarczy sądom narzędzie pomocne w pouczaniu i dyscyplinowaniu uczestników ${ }^{27}$.

Praktyczną korzyścią płynącą z wprowadzenia w życie autonomicznej regulacji odnoszącej się do nadużycia prawa procesowego byłoby także to, że ustawodawca mógłby expressis verbis uregulować skutki podejmowania tego typu zachowań, w tym w szczególności przesądzić, czy sankcją za dokonanie czynności obarczonej taką wadliwością będzie jej bezskuteczność czy też wyłącznie uciążliwości o charakterze dyscyplinującym, niemające wpływu na tok postępowania, takie jak wymierzenie nadużywającemu kary porządkowej czy nałożenie na niego obowiązku zwrotu dodatkowej części kosztów postępowania. Odrębna regulacja pozwoliłaby również rozwiać szereg innych wątpliwości, związanych np. z momentem orzekania w przedmiocie uznania danego zachowania za przejaw nadużycia prawa procesowego, tj. czy organ procesowy powinien rozstrzygać $\mathrm{w}$ tej kwestii przy okazji każdego dostrzeżonego nadużycia, czy może ocenić je en bloc-dopiero w orzeczeniu kończącym postępowanie $\mathrm{w}$ danej instancji (por. art. $226^{2}$ k.p.c.). Co więcej, sądy karne wyposażone w narzędzie tego typu mogłyby w przyszłości korzystać z dorobku orzeczniczego sądów cywilnych, które na przestrzeni kilku lat powinny, przynajmniej częściowo, zawęzić obszar niejasności nagromadzonych wokół tej instytucji. Innymi słowy nie bez racji byłoby twierdzenie, że racjonalny ustawodawca nie powinien rozwiązywać problemów wspólnych dla więcej niż jednej gałęzi prawa w odmienny sposób (jeżeli oczywiście nie ma ku temu dostatecznych powodów), ale zdecydować się na zażegnanie ich przy użyciu jednej, starannie przemyślanej metody, w związku z czym również opowiadam się za wprowadzeniem ogólnej klauzuli nadużycia uprawnień.

Jak trafnie zauważył J. Kosonoga, regulacje dotyczące niektórych etapów procesu już teraz zawierają własną klauzulę, którą - rzecz jasna nie wystrzegając się pewnych uproszczeń - można by nazwać „małą klauzulą nadużycia uprawnień". Przykładem tego typu rozwiązania jest treść art. 372 k.p.k., który upoważnia przewodniczącego składu orzekającego do wydawania verba legis wszelkich zarządzeń niezbędnych do utrzymania na sali sądowej spokoju i porządku ${ }^{28}$. Wydaje się, że na etapie podejmowania decyzji o wszczęciu lub dalszym prowadzeniu postępowania podobną rolę mógłby pełnić art. $17 \S 1$ pkt 11 k.p.k., odsyłający do bliżej niezdefiniowanej „innej okoliczności wyłączającej ściganie”. Być może

27 M.G. PlebaneK: Nadużycie praw procesowych..., s. 537.

28 J. Kosonoga: Oddalenie obstrukcyjnego wniosku..., s. 20 i cytowana tam literatura. 
mogłoby to mieć miejsce m.in. w przypadku wystąpienia przez oskarżyciela publicznego $\mathrm{z}$ aktem oskarżenia świadomie obejmującym zaledwie czyn jednostkowy wchodzący w skład ustalonego przez organy ścigania czynu ciągłego, wyłącznie w celu sprawdzenia (przetestowania), na potrzeby przyszłego postępowania dotyczącego pozostałych elementów tego czynu, mocy dowodowej zdobytego dotąd materiału (w myśl wypracowanej w orzecznictwie reguły, zgodnie z którą stan powagi rzeczy osądzonej, wynikający z wyroku skazującego za czyn jednostkowy, ogranicza się wyłącznie do tego czynu i nie stoi na przeszkodzie późniejszemu osądzeniu innych zachowań, choćby te później sądzone zachowania zostały uznane za czyn ciągły obejmujący czasem trwania również uprzednio osądzony czyn jednostkowy ${ }^{29}$ ). Ewentualna decyzja w przedmiocie niezgodności z celem ustawy odnosiłaby się oczywiście do tego późniejszego aktu oskarżenia. W niektórych wypadkach ten sam wybieg mógłby posłużyć stronie do uzyskania w toku prima facie bagatelnej sprawy korzystnego dla niej orzeczenia zawierającego rozstrzygnięcie o charakterze konstytutywnym, które wraz z częścią stanowiących jego podstawę ustaleń faktycznych wiązać będzie sąd orzekający w późniejszym procesie karnym, tym razem cechującym się znacznym ciężarem gatunkowym.

Uważam, że nadużycie prawa procesowego jako zjawisko istnieje w procesie karnym bez względu na decyzję czy nawet świadomość ustawodawcy w tym względzie, w związku z czym - abstrahując od oceny zasadności wprowadzenia stosownej klauzuli ogólnej - należy podjąć próbę odnalezienia ewentualnej podstawy normatywnej sankcjonowania tego typu zachowań na gruncie obecnego kształtu polskiej procedury karnej.

Tę część rozważań warto rozpocząć od spostrzeżenia, że choć przy okazji definiowania tytułowego pojęcia odniosłem się do celu (celów) konkretnego uprawnienia procesowego (ściślej: celu wprowadzenia normy prawnej, z której uprawnienie to się wywodzi), to jednak duża część autorów zestawia nadużycia prawa procesowego z celem całego procesu karnego jako takiego ${ }^{30}$. Myśl ta dość intuicyjnie odsyła nas do art. 2 § 1 k.p.k.,

29 Post. SN z dnia 8 kwietnia 2014 r., IV KK 66/14. OSNKW 2014, nr 10, poz. 75; post. SN z dnia 30 września 2014 r., II KK 232/14. LEX nr 1554259; wyr. SA w Warszawie z dnia 3 lutego 2016 r., II AKa 352/15. LEX nr 2144810.

${ }^{30}$ M. Niemöller: Nadużycie prawa $w$ procesie..., s. 98; S. Waltoś: O obstrukcji procesowej..., s. 617 i 619 . Rozwiązanie to znacząco przybliża instytucję nadużycia prawa do znanej głównie z państw systemu common law - i co do zasady niezaadaptowanej w krajach kontynentalnych - koncepcji nadużycia procesu (abuse of process), składającej się w istocie tak z nadużyć, jak i „klasycznych” naruszeń prawa procesowego (wskazuje się, że stwierdzenie nadużycia procesu może uzasadniać m.in. naruszenie terminów ustawowych, zniszczenie dowodów, przeprowadzenie nielegalnego podsłuchu czy prowadzenie procesu pod nieobecność oskarżonego); szerzej A. LACH: Nadużycie procesu i uprawnień..., s. 225-228; Ł. CoRA: Gradacja nadużycia prawa..., s. 114-116. 
w którego treści ustawodawca zamieścił wykaz tzw. normatywnych celów procesu karnego. Należy w związku z tym zastanowić się, czy przepisy zawarte w przywołanej jednostce redakcyjnej tekstu prawnego - tj. poszczególne punkty - można by uznać za podstawę prawną kompetencji organu procesowego do sankcjonowania przejawów nadużycia prawa. Jak pisał S. Waltoś, art. 2 k.p.k., z uwagi na niski stopień jego szczegółowości, nie może stanowić samoistnej podstawy decyzji likwidującej nadużycie prawa procesowego ${ }^{31}$. Z tych samych powodów przyjmuje się, że regulacja ta nie może stanowić również samoistnej podstawy zarzutu odwoławczego $^{32}$. Być może zatem a contrario mógłby on stanowić podstawę takiej decyzji wespół z innym unormowaniem prawnym (jako podstawa niesamoistna), tak jak może stanowić skuteczną podstawę zarzutu odwoławczego $\mathrm{w}$ powiązaniu $\mathrm{z}$ innymi przepisami prawnymi ${ }^{33}$.

Funkcję przepisów stanowiących brakujący element poszukiwanej podstawy prawnej de lege lata mogłyby pełnić unormowania odwołujące się do pojęcia niedopuszczalności, o którym mowa w art. 170 §1 pkt 1 k.p.k. (zgodnie z którym należy oddalić wniosek dowodowy, jeżeli przeprowadzenie dowodu jest niedopuszczalne) czy w art. 429 § 1 in fine k.p.k. (stanowiącym podstawę do odmowy przyjęcia niedopuszczalnego środka odwoławczego). W literaturze przyjmuje się wprawdzie, że czynności procesowe są niedopuszczalne, gdy ustawa wyraźnie zakazuje ich przeprowadzenia, równocześnie jednak zastrzegając, że elementem warunkującym zgodność czynności z przepisami prawa może być także cel dokonania ${ }^{34}$. By odpowiedzieć na pytanie, czy zachowanie sprzeczne $\mathrm{z}$ art. 2 $\$ 1$ k.p.k. może być w pewnych warunkach uznane za niedopuszczalne, należy zastanowić się nad jego treścią normatywną. Uważam, że przy zastosowaniu odpowiednich wnioskowań i reguł wykładni przepis ten może być traktowany nie tylko jako deklaracja czy też wskazówka interpretacyjna,

31 S. WaLtoś: O obstrukcji procesowej..., s. 618.

32 Wyr. SN z dnia 25 stycznia 1971 r., IV KR 247/70. OSNKW 1971, nr 7-8, poz. 117; wyr. SN z dnia 8 października 1998 r., III KKN 282/97. PiP 1999, nr 2, poz. 5; wyr. SA w Łodzi z dnia 7 lutego 2001 r., II AKa 269/00. PiP 2002, nr 10, poz. 18; A. SAKowicz. W: Kodeks postępowania karnego. Komentarz. Red. IDEM. Wyd. 8. Warszawa 2018, s. 16. Warto jednak zauważyć, że w literaturze wyrażono także pogląd odmienny - zob. I. NowiкowsкI: O zasadzie szybkości postępowania $w$ polskim procesie karnym (zagadnienia wybrane). W: Państwo - prawo - myśl prawnicza. Prace dedykowane Profesorowi Grzegorzowi Leopoldowi Seidlerowi $w$ dziewięćdziesiąta rocznicę urodzin. Red. A. Korobowicz et al. Lublin 2003, s. 175.

33 Post. SN z dnia 30 lipca 2008 r., II KK 93/08. OSNwSK 2008, nr 1, poz. 1555; por. P. Hofmański, E. SADZIK, K. ZgrYZEK. W: Kodeks postępowania karnego. T. I. Komentarz do artykułów 1-296. Red. P. Hofmański. Wyd. 4. Warszawa 2011, s. 38.

34 Tak trafnie J. Skorupka. W: Proces karny. Red. IDEm. Wyd. 2. Warszawa 2018, s. 347348. 
ale również jako pełnoprawna norma (bez względu na niski stopień jej konkretyzacji), zgodnie z którą należy dążyć do osiągnięcia celów w niej wskazanych. Jeśliby przyjąć, że norma ta jest skierowana także do stron procesu, to instrumentalnie wynikać z niej będzie także norma zakazująca im podejmowania wszelkich działań uniemożliwiających osiągnięcie tych celów. Tym samym naruszenie tej normy zakazu (z uwagi na jej stopień ogólności możliwe do zakwalifikowania jako nadużycie) poprzez zgłoszenie wniosku dowodowego lub wniesienie środka zaskarżenia sprzecznych z celami procesu karnego uzasadnia odmowę ich uwzględnienia lub przyjęcia z uwagi na ich niedopuszczalność. Powyższe rozważania należałoby oczywiście mutatis mutandis odnieść także do innych przepisów wyrażających cele danego etapu bądź trybu procesu karnego, do których de lege lata należą art. 297 k.p.k., dotyczący celów postępowania przygotowawczego, oraz art. $114 \$ 1$ Kodeksu karnego skarbowego ${ }^{35}$, regulujący dodatkowe cele postępowania w sprawach o przestępstwa skarbowe i wykroczenia skarbowe. Swoistą wariacją tej propozycji byłoby uczynienie częścią składową podstawy prawnej przeciwdziałania nadużyciu prawa procesowego przepisów wyrażających poszczególne zasady procesowe, skoro i one, tak jak cele, wyrażają wartości fundamentalne dla całego procesu karnego ${ }^{36}$.

Wadą obu tych koncepcji względem postulatu wprowadzenia klauzuli ogólnego zakazu jest to, że cele wyrażone w ustawie nie są przecież jedynymi celami procesu karnego (chociażby z uwagi na istnienie tzw. celów doktrynalnych), a zasady wyrażone wprost w ustawie procesowej nie wyczerpują całości katalogu zasad procesowych (istnieje bowiem również szereg tzw. zasad nienazwanych). Co więcej, znaczna część szczegółowych rozwiązań procesowych nie wyraża ścisłego związku z żadnym z celów normatywnych ani z żadną ze skodyfikowanych norm-zasad. Skoro więc cele i zasady odnoszone są nie do konkretnych instytucji prawnych, ale do procesu jako całości, to szereg zachowań podjętych nawet z rażącym naruszeniem celu normy stanowiącej ich podstawę pozostałby przez to bezkarny, tj. znajdowałby się poza zakresem zastosowania tak skonstruowanej podstawy prawnej sankcjonowania nadużyć prawa procesowego. Swoistą „ułomnością” zaproponowanej koncepcji jest wreszcie to, że aktualnie do nielicznych należą przypadki, w których ustawodawca przy okazji regulowania określonej instytucji odwołał się wprost do pojęcia niedopuszczalności (ewentualnie innego zwrotu o co najmniej zbliżonym

35 Ustawa z dnia 10 września 1999 r. - Kodeks karny skarbowy, Dz.U. 2018, poz. 1958.

36 Por. poczynione jeszcze na gruncie poprzedniego stanu prawnego rozważania M. Siewierskiego, którego zdaniem każdy z opisanych w ustawie celów procesu karnego jest równocześnie wyrazicielem jednej z jego naczelnych zasad procesowych (M. SIEWIERSKI. W: Kodeks postępowania karnego. Komentarz. Red. M. Mazur. Warszawa 1971, s. 10-11). 
znaczeniu), co oznaczałoby, że - o ile oczywiście konkretne zachowanie nie jest objęte hipotezą jednej z małych klauzul nadużycia uprawnień organy procesowe pozostaną bezsilne wobec licznych przejawów nadużycia prawa procesowego.

\section{Podsumowanie}

Przeprowadzona wyżej analiza prowadzi do wniosku, że omawiane $\mathrm{w}$ niniejszej pracy zagadnienie $\mathrm{w}$ dalszym ciagu stanowi przedmiot rozlicznych kontrowersji wśród przedstawicieli nauki prawa karnego procesowego, których szczegółowe rozwiązanie z pewnością wymagać będzie dalszej dyskusji oraz być może prac o charakterze monograficznym. Równocześnie jednak dotychczasowe osiągnięcia w tym zakresie pozwalają na poczynienie kilku ustaleń natury ogólnej oraz zaprezentowanie wniosków de lege ferenda.

Uważam, że w toku dalszych badań należy w pierwszym rzędzie z większą ostrożnością podchodzić do uznawania określonych zachowań za desygnat pojęcia „nadużycie prawa procesowego”, ponieważ ich bliższa analiza prowadzić może do wniosku, że stoją one w niezgodności tak z celem, jak i z treścią danej normy, stanowiąc tym samym - jak już była o tym mowa - przykład „zwykłego” naruszenia prawa. Wyodrębnienie opisywanej konstrukcji z założenia ma mieć przecież przede wszystkim walor praktyczny, w związku z czym za bezcelowe uznaję zbytnie skupianie się na czynnościach, z których wadliwością organy procesowe radzą sobie już przy użyciu klasycznych norm regulujących określone instytucje.

Zmiana sposobu patrzenia na normatywną zawartość przepisów wyrażających cele i zasady procesu karnego lub poszczególnych jego etapów, $\mathrm{w}$ połączeniu $\mathrm{z}$ istnieniem wskazanych wyżej małych klauzul nadużycia uprawnień, przynajmniej na razie mogłaby posłużyć jako swoista proteza pełnowartościowego mechanizmu przeciwdziałania oraz zwalczania przejawów nadużycia prawa w procesie karnym (do czasu wprowadzenia wyraźnego zakazu nadużywania prawa procesowego na gruncie postępowania cywilnego przez długie lata zbliżoną funkcję pełnił art. 3 k.p.c., zobowiązujący strony i uczestników postępowania do dokonywania czynności procesowych zgodnie z dobrymi obyczajami), tym niemniej należy się opowiedzieć za celowością wprowadzenia w życie ogólnej klauzuli zakazującej tego typu zachowań, która byłaby wyrazem idei, zgodnie z którą rozstrzygnięcia w procesie karnym muszą się legitymować nie tylko legalnością czy dokładnością, ale także autorytetem moralnym ${ }^{37}$.

37 Tak słusznie Ł. CoRA: Gradacja nadużycia prawa..., s. 115. 


\section{Bibliografia}

\section{Literatura}

Borszowsкi P.: Klauzula przeciwko unikaniu opodatkowania. Wrocław 2017.

ConTI C.: L'imputato nel procedimento connesso. Diritto al silenzio e obbligo di verità. Cedam 2003.

CORA Ł.: Gradacja nadużycia prawa $w$ procesie karnym (zarys teoretyczny). SP 2019 , $\mathrm{nr} 1$.

HofMAŃski P., SAdZiK E., ZgryzeK K. W: Kodeks postępowania karnego. T. I. Komentarz do artykułów 1-296. Red. P. HofMAŃsKi. Wyd. 4. Warszawa 2011.

Kosonoga J.: Oddalenie obstrukcyjnego wniosku dowodowego. IN 2019, nr 1.

LACH A.: Nadużycie procesu i uprawnień procesowych. W: Problemy prawa i procesu karnego. Księga poświęcona pamięci Profesora Alfreda Kaftala. Red. G. RejMAN et al. Warszawa 2008.

MajewsKi J.: Granice dozwolonej obrony w procesie karnym a ryzyko popetnienia przestępstwa przez adwokata wykonujacego czynności obrończe. W: Adwokatura $w$ systemie organów ochrony prawnej. T. 3. Red. J. GIEzEK. Warszawa 2010.

Nadużycie prawa. Red. H. IzDEBSKI, A. STęPKowsKI. Warszawa 2003.

Niemöller M.: Nadużycie prawa w procesie karnym. Prok. i Pr. 2002, nr 9.

Nowiкоwsкi I.: O zasadzie szybkości postępowania w polskim procesie karnym (zagadnienia wybrane). W: Państwo - prawo - myśl prawnicza. Prace dedykowane Profesorowi Grzegorzowi Leopoldowi Seidlerowi $w$ dziewięćdziesiąta rocznice urodzin. Red. A. Кововоwicz et al. Lublin 2003.

PlebaneK M.G.: Nadużycie praw procesowych $w$ postępowaniu cywilnym. Warszawa 2012.

PLebANeK M.G.: Wykonanie nieprawomocnego nakazu zapłaty zaopatrzonego $w$ klauzule wykonalności a zagadnienia nadużycia prawa procesowego i podmiotowego. Glosa do uchwały Sąu Najwyższego z dnia 7 października 2009 r. (III CZP 68/09). „Polski Proces Cywilny” 2011, nr 1.

Sakowicz A. W: Kodeks postępowania karnego. Komentarz. Red. Idem. Wyd. 8. Warszawa 2018.

SIEWIERSKI M. W: Kodeks postępowania karnego. Komentarz. Red. M. MAZUR. Warszawa 1971.

Skorupka J. W: Kodeks postępowania karnego. Komentarz. Red. IDEM. Wyd. 4. Warszawa 2020.

SKorupKa J. W: Proces karny. Red. IDEM. Wyd. 2. Warszawa 2018.

WALtoś S.: O obstrukcji procesowej, czyli kilka uwag o nadużyciu prawa procesowego. W: W kręgu teorii i praktyki prawa karnego. Księga pamiątkowa poświęcona pamięci prof. A. Waska. Red. L. Leszczyński, E. Skrętowicz, Z. HoŁdA. Lublin 2005.

Warchoє M.: Pojęcie „nadużycia prawa” $w$ procesie karnym. Prok. i Pr. 2007, nr 11. 


\section{Akty prawne}

Ustawa z dnia 17 listopada 1964 r. - Kodeks postępowania cywilnego, Dz.U. 2019, poz. 1460 ze zm.

Ustawa z dnia 6 czerwca 1997 r. - Kodeks postępowania karnego, Dz.U. 2018, poz. 1987 ze zm.

Ustawa z dnia 29 sierpnia 1997 r. - Ordynacja podatkowa, Dz.U. 2019, poz. 900 ze zm.

Ustawa z dnia 10 września 1999 r. - Kodeks karny skarbowy, Dz.U. 2018, poz. 1958 ze zm.

\section{Orzecznictwo}

Uchw. SN z dnia 22 września 1995 r., I KZP 31/95. OSNKW 1995, nr 11-12, poz. 74.

Wyr. SN z dnia 25 stycznia 1971 r., IV KR 247/70. OSNKW 1971, nr 7-8, poz. 117.

Wyr. SN z dnia 8 października 1998 r., III KKN 282/97. PiP 1999, nr 2, poz. 5.

Post. SN z dnia 19 października 2006 r., V KK 280/06. LEX nr 198075.

Post. SN z dnia 30 lipca 2008 r., II KK 93/08. OSNwSK 2008, nr 1, poz. 1555.

Post. SN z dnia 8 kwietnia 2014 r., IV KK 66/14. OSNKW 2014, nr 10, poz. 75.

Pos. SN z dnia 30 września 2014 r., II KK 232/14. LEX nr 1554259.

Wyr. SA w Krakowie z dnia 20 maja 1999 r., II AKa 71/99. LEX nr 38103.

Wyr. SA w Łodzi z dnia 7 lutego 2001 r., II AKa 269/00. PiP 2002, nr 10, poz. 18. Wyr. SA w Lublinie z dnia 6 lutego 2002 r., II AKa 222/01. KZS 2003, nr 5, poz. 66.

Wyr. SA w Gdańsku z dnia 15 maja 2014 r., II AKa 101/13. LEX nr 1532571.

Wyr. SA w Warszawie z dnia 3 lutego 2016 r., II AKa 352/15. LEX nr 2144810.

Post. SA w Krakowie z dnia 14 października 1992 r., II AKz 218/92. LEX nr 27794.

Post. SA w Krakowie z dnia 30 listopada 1995 r., II AKo 161/95. LEX nr 28318. Wyr. WSA we Wrocławiu z dnia 21 marca 2019 r., I SA/Wr 1220/18. LEX nr 2656515. 